\title{
CHILDREN'S LITERATURE IN EMPOWERING CHILDREN CHARACTER BUILDING
}

\author{
Syahruni Junaid
}

\author{
Universitas Islam Negeri Alauddin Makassar \\ Syahruni.junaid@gmail.com
}

\begin{abstract}
Children literature will provide children with the chances to respond to any form of literary works. It can give them ability to appreciate the cultures of their own. In another way, children literature can develop children's emotional intelligence and creativity, nurture growth as well as their personality and social skill. Literature has been surround the children's daily life unconsiusly. Therefore, literature itself does not only give pleasure but also influence the children in many things, one of them is their character. Through the stories the children can learn about many traits of character, among others trustworthiness, respect, responsibility, fairness, caring and citizenship, honesty, cooperation, service to others, freedom, responsibility, courage, honesty, and fairness that are served through the characters and characterization created. Literature plays an important role in our lives and character development. Good stories become a part of us. They are also a wonderful opportunity to explore the three components of character: moral knowing, moral feeling, and moral action.
\end{abstract}

Keywords: Children's Literature, Personality, Character

\begin{abstract}
Abstrak
Literatur anak-anak akan memberi anak-anak kesempatan untuk menanggapi setiap bentuk karya sastra. Ini bisa memberi mereka kemampuan untuk menghargai budaya mereka sendiri. Dengan cara lain, literatur anak dapat mengembangkan kecerdasan emosional anak dan kreativitas, memelihara pertumbuhan serta kepribadian dan keterampilan sosial mereka. Sastra telah mengelilingi kehidupan sehari-hari anakanak secara tidak biasa. Oleh karena itu, sastra itu sendiri tidak hanya memberi kesenangan tapi juga mempengaruhi anak dalam banyak hal, salah satunya adalah karakter mereka. Melalui cerita, anak-anak dapat belajar tentang banyak karakter, antara lain kepercayaan, rasa hormat, tanggung jawab, kewajaran, kepedulian dan kewarganegaraan, kejujuran, kerja sama, pelayanan kepada orang lain, kebebasan, tanggung jawab, keberanian, kejujuran, dan keadilan yang dilayani melalui karakter dan karakterisasi dibuat Sastra memainkan peran penting dalam kehidupan dan pengembangan karakter kita. Cerita bagus menjadi bagian dari kita. Mereka juga merupakan kesempatan bagus untuk mengeksplorasi tiga komponen karakter: pengetahuan moral, perasaan moral, dan tindakan moral.
\end{abstract}

Kata Kunci: Sastra Anak, Personality, Karakter

\section{BACKGROUND}

Literature for children has always played an important role in children's life. In the early years of their life, more or less the children need to know what is going on in our earth even in our country. Literature is crucial to the mental, psychological and 
social development of a child (Mwanzi, 1982:3). From that sentence, she tries to explain that the literature is one of tool that can stimulate and being an escape for children to make them find their pleasure while reading a literature.

Afterwards, the literature can give the children experience about what happen in the past and what will happen in the future. Because from that experiences the children can learn the meaning of life from the value of the literature. Lukens (2003:6) also explain that literature helps us to identify and examine fragments of experience and literature helps us to see essential- the meaning and unity of life. It will be guidance for children to know more things in the world. More than anything else, children are curious about what they learn or read about; they have a different opinion about something that they see. But sometimes they are very bored with what they read. According to Kabele (1981:14), the books which are to attract children's attention and to be read by them, have to fulfill certain conditions. It is one of reason why children's literature has to be attractive.

It is hard to imagine a world without books for children. There have been children's stories and folk-tales ever since man first learned to speak. Many of them have been narrated, almost in their present shape, for thousands of years. Children's books, however, are a late growth of literature. Yonge (in Hewins, 2012) says, "Up to the Georgian era there were no books at all for children or the poor, excepting the class-books containing old ballads, such as Chevy Chase, and short tales, such as The King and the Cobbler, Whittington and his Cat."

Children are not little adults. They are different from adult in experience, but not in species, or to put it differently, in degree but not in kind. We can say then of literature for young readers that it differs from literature for adults in degree but not in kind (Lukens, 2003: 8). Literature for children can and should provide the same enjoyment and understanding as does literature for adults.

Before the nineteenth century, very few books were especially written for children. Since then, changing attitudes towards childhood and children's development, along with the increased sophistication of print technology, have led to the development of children's literature as a major industry.

Consider all books written for children to be literature-excluding works such as joke books, cartoon books, and nonfiction works that are not intended to be read from front to back, such as dictionaries, encyclopedias, and other reference material.

It is true that some books are of better quality than thers are, but one person cannot dictate to another what he or she ought to perceive as high quality. Some people consider children's literature to span the age group of birth through 18. Then, youth ages 13 to 18 as adolescent or young adult literature, and literature for youth from birth through age 13 as children's literature . Traditional elementary schools enroll children through sixth grade, and typically children are 12 or 13 years old when they complete elementary school.

It is easy to distinguish between a kid in elementary school and one in middle or junior high school; it is even easy to distinguish between a 13-year-old and a 14- 
year old, simply by asking them. But it is not so easy to distinguish between children's and adolescent literature. The definitions and dividing line are arbitrary at best, and sometimes children will surprise us when they cross over these lines with their reading selections.

Children's literature as a concept is defined as literature exclusively about children. Children's literature refers mainly to stories, poetry, rhymes, folk tales, drama, exclusively created for children such as infants, toddlers and the young people as target audience.

Children's literature which is exclusively written for children seems to rest on three criteria (Oby, 2010: 3): the first is whether the heroes are children or teenagers, the second is whether the themes, that is the ideas, relationships and language, are simple or complex. Literature is literature for children if the ideas, relationship and language are simple. However, literature is not children's literature if the ideas, relationship and language are found too complex whether oral or written. For example, a classic literature like Gulliver's Travels is admitted into children's literature because of simplicity of its ideas, relationship and language. Thirdly, children's literature is often aimed at teaching moral lessons.

The defenition of children literature emphasizes on the fact that children's literature is written for children and, of course, with the needs and the interests children in mind. In another word, children's literature could be defined simply as any kind of material written for, or read by, such group referred as children by any particlar society.

Children are not a little adult. They are different from adults in experience, but not in species, or to put it differently, in degree, but not in kind. Or it can be said that literature for children are different from literature for adult in degree but not in kind. Literature for children should provide the same enjoyment and understanding as does literature for adult.

Children's literature is important because it provides children with opportunities to respond to literature; it gives them appreciation about their own cultural heritage as well as those of others; it also helps students develop emotional intelligence and creativity; it nurtures growth and development of the student's personality and social skills; and it transmits important literature and themes from one generation to the next.

Unconsiusly, literature has been surround the children's daily life. Therefore, literature itself does not only give pleasure but also influence the children in many things, one of them is their character. Through the stories the children can learn about many traits of character, among others trustworthiness, respect, responsibility, fairness, caring and citizenship, honesty, cooperation, service to others, freedom, responsibility, courage, honesty, and fairness that are served through the characters and characterization created. 


\section{Problem Statement}

Realizing the phenomena that literature for children are really surrounded children's daily life, then it must be directly or indirectly influenced their character development. Therefore, in this research, the researcher formulates the question into "how is the literature for children building the children character?"

\section{DISCUSSION}

\section{Illustration and Children's Literature}

One point that makes children different from adult literature is actually the existence of illustration which is believed as useful tool in helping the children's literacy. It is stated by Nodelman \& Reimer Illustration that illustration plays an important role in children's literacy development: "children like pictures and children need pictures" (2003: 274). This statement is also suppoerted by Doonan (1993, p. 57) notes that "the reader scans the picture first, then reads the text, then returns to the picture to reinterpret in the light of the words" so that "[the] words help us to interpret the pictures and vice versa". However, Lewis (2001, p. 59), observes that there are good reasons for believing that children read picture-books in ways that adults do not:

Consider the fact that children born into the first years of the twenty-first century are likely to possess a richer and more deft understanding of visual imagery and its modes of deployment than any other generation in the history of humankind. Their world is saturated with imagines, moving and still, alone and in all manner of hybrid combinations with texts and sounds. This is the world in which they must function. Whereas when adults read, they tend to ignore many of the details of accompanying illustrations, children tend to pay careful attention to them (Kiefer, 1993).

Eventhough a popular books in the view of adult, they will not automatically be popular with children also. Therefore, Pascoe and Gilchrist (1987) conducted a survey of a sample of Australian children (aged 10 to 12) to find out what they regarded as important related to their enjoyment of books. And the result showed that presentation, including illustration, is the most important factor. In line with that, Wilson (2000), on the basis of a similar survey, also found out that for a sample of children aged 8 to 11 , book covers were a critical point for children in deciding whether to buy a book. or not. Choosen book covers mostly has an attractive eyecatching visual elements. Another survey, Arizpe (2003, 65) notes that "[almost] without exception, the children thought the pictures were more interesting than the words". They felt that a book would still be good if you only had the pictures, "but if there were only words it would be boring, especially, they added, for children".

The most favorite genre in children's lietarture is picture book. But, there is generally considered to be a difference between an illustrated book and a picture book although there is no clear-cut distinction, with what are sometimes referred to as 'picture story books' falling somewhere between the two categories. Norton (1999, 214), notes that “most children's books are illustrated, but not all illustrated children's 
books are picture books." According to Anderson $(2006,11)$, a picture book "conveys its message through a series of pictures with only a small amount of text (or none at all)". Bader $(1967,1)$ refers to a picture book in the following terms: "text, illustrations, total design; an item of manufacture and a commercial product; a social, cultural, historical document; and foremost, an experience for a child", noting that "as an art form it hinges on the interdependence of pictures and words, on the simultaneous display of two facing pages, and on the drama of the turning of the page". "On its own terms", he claims, "its possibilities are limitless". Nikolajeva and Scott $(2000,262)$ claim that "picture books successfully [combine] the imaginary and the symbolic, the iconic and the conventional, achieved something that no other literary form has mastered."

According to Huck et al. $(1997,11)$, the pictures in picture story books "must help to tell the story, showing the action and expressions of the characters, the changing settings, and the development of the plot". The interconnection between text and pictures in picture story books can provide children an opportunity to develop visual-reading competence as well as provide an excellent opportunity to reinforce and practice language. Therefore, it is important that parents or teachers should know how children view the pictures in picture books and picture story books, what types of picture appeal to children and how pictures can best be used to help children with their language development. Stewig (1992, p. 12) argues that there are three stages in the development of picture reading as an aspect of children's multi-literacy:

1) [Bringing] personal meaning to ... units (comparing/contrasting the author's text with their own background knowledge and experience).

2) [Examining] . . . individual units for picture clues in the context of larger units (similar to looking at vocabulary in the context of sentences).

3) [Extracting] meaning from the words and sentences (discover the author's meaning through the use of text clues).

\section{Good children's literature}

Many writers appear to believe that the question of what constitutes 'good' children's literature can be addressed without taking direct account of context of use. The good quality of children's literature should be fulfilled the criteria of literary elements, (a) fictional elements (p. 22), (b) visual elements (p. 28) and (c) nonfictional elements (p. 170). (Tomlinson and Lynch-Brown (2002) which are simply stated as follow:

\section{a. Fiction elements}

- Plot -

A good plot produces conflict in order to build the excitement and suspense that can easily invite children to get involved. Plot in children's literature is playing very important role because a good story comes from a good plot. As we know that most children learn by what they see, they watch even they read. So, the plot in 
children's literature should be suitable with the children themselves, in other words it should be considered as something good to build the children's character.

- Characters - Characters must be memorable. The main characters in an excellent work of fiction for children are fully-developed, undergoing change in response to life-alerting events. The well-depicted character will be a good role model, or best friend for a child. An imaginative writer presents diverse characters that serve an opportunity for a child to contrast or compare all the character traits and to pick his favorite character as his best role model in real life. But still the role of parents to guide and direct the children to follow the good manner character is absolutely needed in reading the children's books.

Roald Dahl in his magnificent work "Charlie and The Chocolate's Factory" succeed to create a variety of characters. He presents fifth children from different social background winning the golden ticket from Willy Wonka's chocolate company, the first and best chocolate factory in the world.

- Setting - $\quad$ The setting is an integral part of a story, which includes time and place. Although setting is often vague in traditional literature for children, detailed descriptions of settings can be an effective way of engaging children's interest.

- Theme - $\quad$ Themes in children's books should be worthy of children's attention and Ishould convey truth to them. Furthermore, themes should be based on high moral and ethical standards. A theme must not overpower the plot and characters of the story, however; children read fiction for enjoyment, not for enlightenment. Children, depicted by Schanzer, is considered being able to improve their selfconcepts and to develop their cultural identity by reading multicultural literature. Furthermore, by knowing those people who belong to racial and ethnic groups other than theirs can support children to realize that they also need similar to them - not stereotypes. Then, even containing a little bit didacticism, multicultural theme teaches children in what way the majority culture must behave to respect the values of minority groups in the world.

- Style - $\quad$ Style is the way in which an author tells the story; it is an aspect of the writing itself, as opposed to the content. Style should be appropriate in relation to content. The elements of style include word choice, sentence selection and book organization. The words should be appropriate to the story told; sentences should be easy to read but melodic, and the paragraphs, length of chapters, headings 
and chapter titles, preface, endnotes, prologue, epilogue, and length of the book overall should be designed with children's age and stage of development in mind.

\section{b. Visual elements}

- Line - Lines are the stroke marks that form part of the picture. The line of a picture generally defines the objects within the picture. Artists may choose to use lines that are dark or pale, heavy or light, solid or broken, wide or thin, straight or curved, or have combinations of these elements. The lines of the picture should help to create and convey both the meaning and the feeling of the story.

- Colour - Colour can be described in terms of its hue, lightness, and saturation. Colours must be used to complement text. For example, soft warm tones are associated with calmness and contentment. Colours should change appropriately according to the story lines. If the events and mood of the story change during the course of the story, then the colors should change to reflect the shifts in the story.

-Shape - Shapes are evaluated for their simplicity or complexity, their definition or lack of definition, their rigidity or suppleness and their sizes. For example, negative or blank space may be used to highlight a particular object or to indicate isolation or loneliness. The shapes in a picture, the spaces surrounding the shapes and the proportion of objects in relation to one another are important aspects of non-verbal messages.

- Texture - $\quad$ Texture conveys the impression of how a pictured object feels and can add a sense of reality to illustrations. Textures can be rough or slick, firm or spongy, hard or soft, jagged or smooth.

- Composition - Composition includes the arrangement of the visual elements within a picture and the way in which these visual elements relate to one another. The compositional characteristics of illustrations can help to convey an overall sense of unity and can reinforce aspects of textual meaning.

c. Non-fictional element

- A clear, direct, easily understandable style is critical. Stylistic devices such as the inclusion of questions including the second person pronoun (you), as in "Have you ever wondered how chameleons change colour?" can stimulate readers' interest and involvement.

- Captions and labels should be clearly written and informative. Though brief, these pieces of text serve the vital function of explaining the significance of illustrations or of drawing the reader's attention to important or interesting details. 
- Facts should be accurate and current. Non-fiction should distinguish clearly between fact, theory, and opinion.

- Personification should be avoided. Attributing human qualities to animals, material objects, or natural forces is part of the charm of works of traditional and modern fantasy. However, it should be avoided in nonfiction.

- Attractive presentation. Works of non-fiction should be attractively packaged and presented. An intriguing cover, impressive illustrations, and appropriate balance between text and illustrations can make nonfiction more attractive to children.

- Movement from known, simple and general to unknown, more complex and specific. To aid conceptual understanding and encourage analytical thinking, presentation of information should be from known to unknown, general to specific, and simple to more complex.

- Stereotyping should be avoided. The best non-fiction goes beyond mere avoidance of sexist or racist language and stereotyped images in text and illustrations. It also shows positive images of cultural diversity.

- Format and artistic medium should be appropriate to the content. The exactness, clarity, and precision of photography, for example, make this medium appropriate for authors whose purpose is to present the world as it is.

- Depth and complexity of subject treatment must be appropriate for the intended audience. If an explanation must be simplified to the extent that facts must be altered before a child can begin to understand, the concept or topic is inappropriate in terms of the age and/or conceptual development of the intended audience.

According to Mwanzi, (1982:3) literature is crucial to the mental, psychological and social development of a child. This brings to the understanding that children's literature could be used to teach a variety of lessons, morals, and ideas. Literature stimulates children's imagination and sharpens their awareness of the world around them. Considering that childhood is an important stage of human development. Okolie (1998 quoted in Muleka 2001: 13), says this, "In the beginning, there was childhood and childhood makes the man or woman". This could be translated that the stage of childhood could determine the kind of adult to be expected in future. This therefore calls for greater attention from scholars who have concerned in children's literature to consider that it is an important factor in shaping the character of children.

Since childhood is a crucial stage in the development of an individual, the quality of books availed to children at this stage becomes a major concern because children respond to what they read, (Muleka 2001: 4). For instance, Tucker (1976:180) observes that children have to learn conventions and some stories with clear conventions are helping children who are trying to build up some ways of predicting the immediate future. This observation could mean that children internalize what they read in books and this internalization may shape their behavior as adults. 


\section{Children's Literature in Empowering Children Character Building}

Literature is a powerful vehicle for helping children understand their homes, communities and the world. Even before young children can read, family members, childcare providers and teachers read them stories about people in faraway places, sometimes from the distant past and sometimes about people whose lives are similar to their own. The impressions and messages contained in these stories can last a lifetime.

Books, at their best, invite children to use their imaginations, expand their vocabularies and gain a better understanding of themselves and others. If the books reflect the diverse groups of people in the world around them, children can learn to develop respect for self and others. Literature should be both a mirror in which children can see themselves reflected, and also a window through which children can explore the world around them; books can illustrate the concept that people from diverse groups can play and work together, solve problems, and overcome obstacles. At its best, multicultural children's literature helps children understand that despite our many differences, all people have feelings and aspirations. Those feelings can include love, sadness, fear, and the desire for fairness and justice. Following are a few of the specific benefits children derive from reading and listening to books (Cullinan, 1992):

1. Strengthening a bond between the child and adult reader

2. Experiencing the pleasure of escaping into a fantasy world or an exciting adventure

3. Developing a favorable attitude toward books as an enrichment to their lives

4. Stimulating cognitive development

5. Gaining new vocabulary and syntax

6. Becoming familiar with story and text structures

7. Stimulating and expanding their imaginations

8. Stretching attention spans

9. Empathizing with other people's feelings and problems

10. Learning ways to cope with their own feelings and problems

11. Widening horizons as they vicariously learn about the world

12. Developing an interest in new subjects and hobbies

13. Understanding the heritage of their own and other cultures

14. Acquiring new knowledge about nature

15. Bringing history to life

16. Stimulating aesthetic development through illustrations

17. Exploring artistic media used in illustrations

The problem of character education in building character is actually a universal problem. There are many leterary texts that are believed as having moral elements and values that can be used as the raw material in education and character 
building. The literary texts are cosidered having the educating elements because there is no authors who wrote their literary works without moral messages. Conventionally, literature used by hereditary parents to educate children.

We often do not realize that the things and activities that we do, or others, also by children, is a literature nuance of life. Then, it is not an exaggeration to say that in fact we live surrounded by literature (children). There are various examples of the circumstances and events which show the condition and activity of literature for children all around us in our daily lives. From the circumstances, children's literature is actually something very familiar and at the same time we can use as a strategic means to plant, nurture, and develop a range of values that we want to inherit at the character building.

A variety of things and activities are exemplified below:

a. When the child cries or the mom wanted to please her child, she will sing a song or lullaby until the baby still and giggling happy.

b. When the child flip through books and pictures which she served, the mom will show and teach their names or pictures, letters, or numbers related so that the child looks pleased to understand.

c. When the child go the bed, the mother recalled a story, either the story has ever heard, read, or stories create by herself, and either already repeated many times, until the child is asleep brings his story to dreamland with a very charming smile.

d. When the kindergarten kids with their clear eyed and adorable are so crowded, the teacher will tell a storyuntil the children are stunned, amazed, lulled, or cheering joy for being so enthusiastic and animates. Actually, what is done by the mother and teacher is nothing but the activity of using literature in daily life with children.

Children's literature coverage extends widely once, or common known as genre, even surpass the scope of the adult literature. It is oral, written, even activity. Oral literature could be the story of the mother to her child, the mother of the teacher to the students in her kindergarten, elementary students class initially, chants, songs, traditional songs, lullaby, etc. Written literature can be a variety of things which are intentionally written for children and stressed the importance of the elements of beauty. So, it can be poetry, fiction, biography, history, various types of book information, the script plays, and others that often accompanied the interesting pictures. Literary activity is something that is in the form of appearance such as drama, poetry recitation, reading and even finger-rhyming (such knocking the fingers on the table to form a certain rhythm pattern).

Many literary works containing values of character education that is both sublime and entertainment value. By reading literary works, readers will find a wide range of issues in life, various human characters, unlock creativity and innovation opportunities for readers to be a good human character. Literature contain elements of 
imagination, experience and values of life. Stories around the world either orally or written is a product that is consumed, among others the goal is the education of ethics and character. Hans Christian Anderson from Denmark, for example, deliberately write beautiful stories that spread across the world to bring children on dreams in beauty and the sublime character.

The age of the child is the age where the learning process is started. The child begins to learn to see the world using their senses. They began observing, by way of a hearing, seeing, then mimicked their observationally (Bandura, 1986). In his theory of observational learning theory, Albert Bandura argued that children learn through observation, limitations, modeling (see the other as a model). This theory is known as the bridge between behavioral and cognitif learning because it is moving among attention, memory and motivation.

In learning, cognitive and social factors play a very important role. Children imitate the people nearby and surrounding their environment. Imitating is done through a process that is repeated. The continual repetition lead to forms of intimidation on the child to the things being done in their closest environment. The repetitions in a systematic but sometimes without realising according to Bourdieu referred to as habituation process. On the early age, the child gets any messages that contain elements of ethics, morals, and virtues of goodness of character undertaken by the elderly and the environment shaping them. Habituation processes started in various ways to the moral messages to them.

One form of the conditioning process often is done around the world by the parents or teachers at school by way storytelling. In indonesia, for example, with the oral tradition of storytelling is done by the parents to accompany their children to sleep. A story before bed is sometimes a narratives hereditary, like Cinderella, Golden Snail and so on. The story is sometimes their own creations by adopting messages that children formed their self identity. These stories are usually formed contains compliance toward parents, honesty, love, independence, as well as other forms of moral education among others.

Another popular narrative is through children's literature which is already in written form. The form of storytelling through the medium of this literature, is very popular in the Western world since long time ago. Parents in storytelling usually do so by reading out stories to children before they go to sleep. The tradition of Western society is a written tradition transferred from generation to generation in the purpose of the formation of their character. In the context of Indonesia, reading books to children is also done on the hours of study or the hours they are playing. In addition to the child who is already starting to read, reading is part of the conditioning process to shape their character.

The construction through conditioning because consumed massively by the children is indeed happen not directly because it is not contained in the story. It means that the story contains the good things. However, the formation of which accompanied the story into something that is consumed by children. Thus, the consumption will 
shape their views. Choosing the things that are positive for the child's development is a very important thing to do. This is because children do not consume a total way on the content of the story but on other elements captured by their senses. In developmental psychology that many are written by Bandura (1986) as explained above, the observational learning is one of the important level in the development of the child. Many children learn by observing using the sense of eyes. After that, the child then imitate their results of observation. The problem is they then can imitate the actions which are not part of the story, such as violence. Hence, it is required the guide of parents when they are reading or watching television.

Dealing with children's literature means dealing with the question of the content of stories from children's literature that contained characters that are considered good in the community. Positive things is extremely important as input for parents and educational institutions.

Things that needed to be elaborated to give input to the development of children's characters are as follow:

1. The characters either positive or negative built by good children's literary work extrinsically and intrinsically can become input at once criticism for a model of character character development.

2. Ideologies offered by children's literary work can contribute on children's development character.

3. Children's character model can be built based on the various contributions of both intrinsic and extrinsic from literary works as well as of the role of ideology and related media industry in the process of consumption and reproduction of literary works for children.

Children's literature is a great resource because it can be used to teach a variety of topics (Prestwich, 2004). Children's literature helps students begin to discuss and think about character education, but has been found that having discussions after reading the selected books can improve the books' effectiveness on the students' attitudes about character traits (Auciello, 2006; Clare \& Gallimore, 1996; O’Sullivan, 2004; Smith-D'Arezzo \& Moore-Thomas, 2010). The use children's literature has been beneficial in changing attitudes.

Despite seeming to be a method, children's literature should be used to teach character education because "internalizing behaviors (e.g. displays of sadness or depression) were more common as well at the elementary and high school levels" (Wagner et al., 2006, p. 21). Thus, teaching children to empathize and problem solve through literature selections that have specific morals may help to decrease the number of children who internalize such behaviors.

Literature can be a good way to teach character education because "literature lends itself to the teaching of specific moral dilemmas and the examining of specific character traits" (Prestwich, 2004, p.143). Chilren are able to empathize with the 
characters and understand character traits better than just being told information about each trait, also known as catharsis, or the connection between the reader and the characters (Lowe, 2009; Prestwich, 2004). Literature can assist in discussing difficult topics such as incarceration, bullying, death, and abuse. Literature can provide students with emotional and social support for things they might also be going through; thus, the use of literature may be a useful method to discuss difficult topics (Jalongo, 2004; Lowe, 2009). "Expression through text offers readers of all ages the opportunity to find solutions through the character and conflicts within a story, and thus within themselves" (Lowe, 2009, p.1). In addition, and perhaps most importantly, children's literature should be used to teach character education because picture books attract children, communicate ideas, and the visual images leave "the most indelible impression" (Jalongo, 2004, p.38). The students often relate to the characters and pictures in these books rather than non-picture books, which adds to their effectiveness. The pictures aide the students in understanding the abstract concepts taught in character education stories, which is another reason why picture books are beneficial for teaching character education to young children. Furthermore, children are more likely to respond to storytelling because it is seen as a gift from the teacher (Sanchez \& Stewart, 2006).Thus, students are more likely to internalize and remember the lessons that they learn from these stories.

Literature is indeed able to give pleasure and enjoyment, but it also contained "giving pleasure". What benefits can afford given by literature? The answer may be to involve various aspects of life that support the formation of character. It also seems to be the cause of literature was able to survive from generation to generation. The literature contains and or reflect an attitude of life in literary works where and when it was created.

Literature plays an important role in our lives and character development. Good stories become a part of us. They are also a wonderful opportunity to explore the three components of character: moral knowing, moral feeling, and moral action (Mosher,2001).

\section{Moral Knowing}

We must first know right from wrong in order to evaluate and make choices. One aspect of moral knowing is perspective-taking. As children experience the world from the viewpoint of a character in a story or evaluate the decisions characters make, their cognitive and moral skills develop.

In Who Belongs Here? a Cambodian refugee boy confronts schoolmates who call him chink and tell him "get back on the boat and go home where you belong." The author asks, "What if everyone whose ancestors came from another country was forced to return to his or her homeland?" As children discuss the boy's experiences and their own experiences with name-calling and unfairness, they consider how words and actions affect others and each person's right to respect. 
In The Bobbin Girl, a historical tale based on real events in the 1800s, a girl in a textile mill stands up for workers' rights. The narrator does not make the same sacrifices but will always know what was right.

We All Sing With The Same Voice, a song from Sesame Street made into a fine book, "embraces the notion that no matter where children live, what they look like, or what they do, they're all the same where it counts - at the heart." In understanding others' perspectives, we realize what we have in common.

\section{Moral Feeling}

As children consider how it feels to have done the right thing or the wrong thing, they develop the emotional side of their moral response to literature and their own lives.

In Esmeralda and the Children Next Door, neighbor children realize they have hurt a friend and strive to make amends. Esmeralda is a big child and is taunted and rejected because of her size. Size discrimination is a problem in many schools that can go unrecognized and unaddressed.

How To Be A Friend: A Guide to Making Friends and Keeping Them helps children recognize and take steps to resolve issues of friendship in a straightforward way.

\section{Moral Action}

Even young children know that people who "talk the talk" must "walk the walk." In The Summer My Father Was Ten, each time they plant a garden, a girl's father tells a story from his childhood. He recounts how a ball game turned tomato fight and an old man's garden was ruined. The boy's remorse turned to action and friendship the next spring when he helped the man plant a new garden.

In Uncle Willie and the Soup Kitchen, a boy accompanies a neighborhood caretaker to the soup kitchen, where he learns more about homeless and hungry people and the volunteer work done to help them. Kids Explore Kids Who Make a Difference tells of real children who have gotten involved in the world and taken moral action. Children Save the Rain Forest tells how children worldwide have worked to save a rain forest in Costa Rica and gives information about what readers can do.

Unfortunately, not all children's literature conveys the messages that we want young people to learn. Books often contain the same stereotypes and biases of other media, and because children are interested in a story's plot and characters, it is unlikely that they will know or consider whether a book includes racist, sexist or other stereotypical messages. If young children are repeatedly exposed to biased representations through words and pictures, there is a danger that such distortions will become a part of their thinking, especially if reinforced by societal biases.

It is, therefore, the responsibility of adults to select literature that is entertaining, age appropriate, and that provides children with accurate representations 
of all people. For example, choosing Cinderella perpetuates the stereotype of the lead female character as passive, dependent and naïve. Chosing Robert Munsch's The Paper Bag Princess which the lead female character is portrayed as brave and independent. Additionally, because there are such a relatively small number of children's books about people of color, people who are gay and lesbian or people with physical and mental disabilities, it is extremely important that adults make every effort to ensure that high-quality children's literature by and about these groups is made available to children. Selecting good multicultural children's books begins with the same criteria that apply to selecting good children's books in general-the literary elements of plot, characterization, setting, style, theme and point of view must be interwoven to create a compelling story in an age appropriate manner. When deciding whether or not to include a particular title in a collection of children's books, it is important to review the illustrations or pictures.

Here are some things to think about when choosing early childhood children's literature. Some of these questions can be used to evaluate a single book; however, the questions are most effective when used to review a complete collection.

\section{STORY:}

a. Are the stories interesting to children?

b. Are there various conflicts for children to explore?

c. How are the conflicts resolved?

\section{CHARACTERS:}

a. Do characters represent people from a variety of cultural groups?

b. Do "good" characters reflect a variety of backgrounds?

c. Are females as well as males depicted in leadership roles?

\section{THEMES:}

a. Does the story offer children a variety of things to think about, to question, and to consider?

b. Are values being explored instead of preached?

c. Are there lessons to be learned?

\section{SETTINGS:}

a. Do the stories reflect a variety of settings?

b. Are urban, suburban and rural settings represented realistically?

c. Are cultural settings represented realistically?

\section{ILLUSTRATIONS:}

a. Are diverse populations represented?

b. Is there diversity represented within cultural groups?

c. Are characters realistically and genuinely represented? 
d. Do the illustrations avoid reinforcing societal stereotypes?

\section{OTHER CONSIDERATIONS:}

a. Will the stories encourage discussions?

b. Are children exposed to multiple perspectives and values?

c. Do the stories promote understanding of our diverse society?

d. Are the stories age appropriate to ensure children can understand what is presented?

While every children's book cannot possibly meet each and every standard of excellence, in many instances, the value of a particular book will outweigh those aspects that might be questionable or problematic. Caregivers should examine children's books for such things as historical accuracy, realistic life styles, believable characters, authentic language and ensure the book is age appropriate. The books chosen should also represent a variety of settings, problem-solving approaches and themes, and should provide opportunities for children to consider multiple perspectives and values. Multicultural children's books should not speak to a limited group of children; they should speak to all children.

\section{Bibliography}

Andersen, Hans Christian. Pangeran Panjang Akal (The Swineherd). PT. Buana Ilmu Populer. Jakarta. 2010.

Andersen, Hans Christian. Pangeran Panjang Akal (The Swineherd). PT. Buana Ilmu Populer. Jakarta. 2010.

Ball, Jacqueline A. Just in Time. PT. Gramedia Pustaka Utama. Jakarta. 2010.

Bezenac, Agnes de and Salem de Bezena. Out and About. iCharacter Ltd. 2012. Bed Making Blues. iCharacter Ltd. 2012.

Brown, Carol Lynch and Carl M. Tomlinson. Essential of Children Literature. Allyn and Bacon. The United States of America 1999.

Brown, Carol Lynch and Carl M.Tomlinson. Essential of Children Literature. 1999.A Viacom company:

. Timun Emas. PT. Happy Holy Kids. Banten. 2013.

Ball, Jacqueline A. Just in Time. PT. Gramedia Pustaka Utama. Jakarta. 2010.

Brown, Carol Lynch and Carl M. Tomlinson. Essential of Children Literature. Allyn and Bacon. The United States of America 1999.

Carrol, Lewis. Petualangan Alice di Negeri Ajaib(Alice's Adventures in Wonderland). PT. Buana Ilmu Populer. Jakarta. 2010.

Carrol, Lewis. Petualangan Alice di Negeri Ajaib (Alice's Adventures in Wonderland). PT. Buana Ilmu Populer. Jakarta. 2010.

Falls, C.B. ABC Book. Doubleday \& Company, Inc. New York. 1923.

Karlin, Nurit. Ten Little Bunnies. Illustrated by Hans Wilhelm. Simon\& Schuster Books for Young Readers. New York. 1994. 
Kiefer,B.Z., Hepler,S.I., Hickman,J. Charlotte Huck's Children Literature. 2007.McGraw-Hill: Boston.

Koesnosoebroto, Sunaryono Basuki. The Anatomy of Prose Fiction. Departemen Pendidikan dan Kebudayan. Jakarta. 1988.

Lukens, Rebecca J. A Critical Hand Book of Children's Literature. Ally and Bacon. The United States of America. 2003.

Medits, Drea. Ogan Si Orang Utan. ANDI. Yogyakarta. 2013.

Muakhir, Ali and Nur Cililia. Dobi Yang Hilang. DAR! Mizan Publishing House. Bandung, 2004.

Mwanza, Pius. 2007. Mtindo wa Nyimbo za Watoto wa Shule za Chekechea. M.A. Thesis. Kenyatta University.

Nata, Koko and Herusutrisno. Kiwi Kaki Besi. PT. Bestari Kids. 2009.

Nurhakim, Syerif and Imam Kr Moncol. Aksi Tiga Pahlawan Cilik. Gurita. Jakata Timur. 2013.

Nurhakim, Syerif and Imam Kr Moncol. Meriahnya Lomba Tujuh Belasan. Gurita. Jakata Timur. 2013.

Olchawska, Magda M. Mikolay \& Julia. Illustrated by Agnieszka Antosiewicz. Mayan Books. 2010.

Rollyson, Carl. American Biography.2006.United States of America.

Riswinanda, Sadia. Negeri Angka Yang Menakjubkan. Tiga Serangkai. Solo. 2006

Salas, Laura Purdie. Apakah Gajah Muat di Tanganmu? (Does Elephant Fit in Your Hand?). PT. Ilmu Buana Populer. Jakarta. 2007.

Salisbury, Martin. Illustrating Children's Book. Barron's Educational Series, Inc. United States. 2004.

Stoodt, Barbara. Children's literature.1996.Gorsuch Scarisbrick: Australia.

Straparola, Geovani Francesco. Kucing Bersepatu Bot (Puss in Boots). PT. Buana Ilmu Populer. Jakarta. 2010.

Susilo, Bambang Joko. Akulah Kayu. Bestari Kids. Jakarta Timur. 2006.

Trim, Mary. Growing and Knowing: A Selection Guide for Children's Literature. K.G. Saur. Munchen. 2004.

Villeneuva, Gabrielle-Suzanne Barbot de. Si Cantik dan Si Buruk Rupa (Beauty and the Beast). PT. Buana Ilmu Populer. Jakarta. 2010.

Wilhelm, Hans. Waldo and The Desert Island Adventure. Random House, Inc. New York. 1986. . Timun Emas. PT. Happy Holy Kids. Banten. 2013. Never Lonely Again. Random House, Inc. New York. 1988. 